\title{
AVRUPA BİRLİĞİ'NDE BÖLGESEL KALKINMA AJANSLARINA GEÇİ̧̧ SÜREÇLERİ VE ÜLKE UYGULAMALARI
}

\author{
Didem SAYGIN \\ Arş.Gör. Dr., Çanakkale Onsekiz Mart Üniversitesi, Biga İİBF, Kamu Yönetimi Bölümü, \\ E-posta: didemsaygin@gmail.com
}

Mehlika Özlem ULTAN

Yrd.Doç.Dr., Kocaeli Üniversitesi, İ̈BF, Uluslararası İlişkiler Bölümü, E-posta: ozlemultan@gmail.com

\section{$\ddot{O Z Z E T}$}

Bölgesel Kalkınma Ajansları, bölgesel politikalar gelişstirerek, bölgelerin kalkınmasını, geri kalmuş bölgelerin iyileştirilmesini ve dolayıslyla birbirleriyle rekabet edebilir hale gelmelerine yardım etmeyi amaçlayan kuruluşlardır. Avrupa Birliği de bölgesel politikalara önem vermekte ve yeni katılan ülkelerin de bölgesel yapılanmalarını uyumlaştırmaları gerektiği düşüncesini savunmaktadır. Bölgesel Kalkınma Ajansları, Maastricht Antlaşması ile oluşturulan Bölgeler Komitesi çerçevesinde işleyişlerini sürdürmektedir. Ancak, Avrupa Birliği'nin üye ülkelerde uyumlu ve ortak bir bölgesel politikaya geçiş aşamasında ne kadar başarılı olduğu tartışma konusu olmaktadır. Bu çalışma çerçevesinde, Birliğe üye olan ülkelerin ortak bir bölgeselleşme süreci yaşayıp yaşamadıkları tartışılacaktır. Bunun için öncelikle bölge ve bölgeselleşme konuları ele alınacak ve bölgesel kalkınma ajanslart değerlendirilecektir. Daha sonra Fransa, Ingiltere, Polonya ve Çek Cumhuriyeti'ndeki bölgeselleşme hareketlerinin işleyişi incelenecektir. Böylece, adı geçen ülkelerin bölgesel kalkınma ajanslarına geçiş süreçleri karşılaştırılmaya çalışılacaktır. 
Anahtar Kelimeler: Bölgesel Kalkınma Ajansları, Bölgeselleşme, Fransa, İngiltere, Polonya, Çek Cumhuriyeti.

\title{
TRANSITION PROCESS IN REGIONAL DEVELOPMENT AGENCIES IN THE EUROPEAN UNION AND COUNTRY APPLICATIONS
}

\begin{abstract}
Regional Development Agencies are organizations which are aiming to help the development of the regions, the improvement of the underdeveloped regions, and thus to be able to compete with each other, via developing regional policies. The European Union gives importance to regional politics and advocates that the new participating countries should harmonize their regional structures. Regional Development Agencies continue to operate within the framework of the European Committee of the Regions that established by the Maastricht Treaty. However, there is a debate about how successful the European Union is in the transition to a coherant and common regional policy in the member countries. Within the framework of this study, it will be discussed whether the countries that are members of the Union have lived in a common regionalization process. First of all, region and regionalization issues will be determined, and regional development agencies will be evaluated. Then, the functioning of the regionalization movements in France, United Kingdom, Poland and the Czech Republic will be examined. Thus, the transition processes of the mentioned countries to regional development agencies will be tried to be compared.
\end{abstract}

Key Words: Regional Development Agencies, Regionalization, France, The United Kingdom, Poland, the Czech Republic.

JEL Codes: P25, R1, N44

\section{GíRiş}

Küreselleşme ile birlikte, rekabet koşullarının değişmesi, ekonomi politikalarının yenilenmesi söz konusu olmuş ve merkeziyetçi politikalar yerini yeni politikalara bırakmaya başlamıştır. Yerellik, yerindenlik ve bölge kavramlarının ön plana çıkması ve bölgelerin kalkındırılmasına yönelik politikaların uygulanmaya başlaması da bu süreçte yaşanmıştır. Merkeziyetçilik kavramından uzaklaşılarak, ülkelerden ziyade ülkeleri oluşturan bölgelerin ekonomik nitelikleri değerlendirilmeye alınmış ve geri kalmış bölgelerin kalkınması adına yapılan çalışmalar devreye girmiştir. Avrupa Birliği de bölgelerin kalkınmasına yönelik bir çalışma süreci içerisinde yer almıştır. Bunlardan en önemlisi ise bölgesel kalkınma ajanslarıdır.

Bölgesel kalkınma ajanslarının kendilerine has uygulama programları bulunmakla birlikte, genel olarak ortak bir bölgesel kalkınma yapısından da söz etmek mümkün olmaktadır. Bu çalışma kapsamında planlanan, bölgesel kalkınma ajanslarına geçiş sürecinde ülkelerine bölgeselleşme aşamalarında benzer durumlar yaşayıp yaşamadığını araştırmaktır. $\mathrm{Bu}$ bağlamda, Avrupa Birliği'nde bölgesel olarak karşılaştırılacak 4 ülke seçilmiştir. Bunlardan ilki olan Fransa, Birliğin kurucu üyelerinden olması ve Avrupa'da ilk kurulan bölgesel kalkınma ajansına ev sahipliği yapmasından dolayısıyla önem teşkil etmektedir. İkinci olarak İngiltere'nin bölgeselleşme süreci araştırmaya tabi tutulmuştur. Polonya ve Çek 


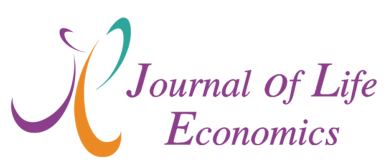

Cumhuriyeti ise hem konum olarak Doğu Avrupa'da bulunmaları, hem de 2004 yılında Birliğe dâhil olan ülkeler arasında olmaları sebebiyle araştırmaya dâhil edilmiştir.

\section{BÖLGESEL KALKINMA İLE İLGİLI KAVRAMLAR}

Bölgesel kalkınma kavramı incelenmeden önce, bölge ve bölgeselleşme kavramları hakkında kısaca bilgi verilmesi yerinde olacaktır. Uluslararası hukuk bağlamında bölge; ortak çıkarları bulunan, coğrafi, siyasal ve ekonomik ilişkiler ağına dâhil olan ülkelerin oluşturduğu bölgesel örgütlenmeler şeklinde tanımlanmaktadır (Mengi, 1998: 43). Bölge kavramı sık kullanılmakla birlikte sahip olduğu sınırlar bağlamında farklılık göstermekte ve ayrıca farklı anlamlar içeren, çok yönlü bir tanım olarak da değerlendirilebilmektedir. Genel olarak bakıldığında bölge kavramının, homojen olma niteliği kapsamında ele alınarak tanımlandığı görülmektedir. Böylece, kendi içerisinde benzer nitelikleri olan ve diğer bölgelerden farklılaşan alanlar bulunup analiz edilerek bölge ayrımına gidildiği söylenebilmektedir (Elmas, 2001: 23). Ayrım yapılırken coğrafi, kültürel, tarihsel, nüfus yoğunluklu alanlar gibi ölçütler temelinde hareket edilebilmektedir. Bunun yanı sıra, bölgeyi ekonomik özellikleri kapsamında ele alarak, ekonomik yapılanmalar, belirli sektörlerin ön planda bulunduğu alanlar ya da aktif olarak ekonomik faaliyette bulunulan alanlar gibi özelliklerine bakarak tanımlamak da mümkündür (Brasche, 2001: 13). Bölgeselleşme kavramı ise bölgeye göre daha yönetsel bir anlam içermekte; yerel ve yönetsel birimlerin merkezi otorite karşısında daha güçlü bir konumda bulunması olarak ifade edilebilmektedir (Mengi, 1998: 45). Yerellik ilkesi (subsidiarity) ise, hizmetlerin vatandaşlara yakın birimler tarafından yürütülmesine yönelik bir kavram olarak karşımıza çıkmaktadır. Avrupa' da yerellik ilkesinin temeli Avrupa Kömür ve Çelik Topluluğu'nu kuran Antlaşmaya dayanmakta ancak, 1992 tarihli Maastricht Antlaşması ile özellikle vurgulanmaktadır. Avrupa Birliği yerellik ilkesiyle, Birlik ve üye ülkeler arasında görev ve yetki paylaşımının yapılması sırasında vatandaşlara yakın karar alınmasını sağlamaya çalışmayı hedeflemiştir (Mengi, 1998: 27).

Bölgesel kalkınma, belli sosyo-ekonomik kriterler kapsamında ortak özelliklere sahip olan ve öncelikle ülke ortalamasının altında kalan alanların sorunlarına çözüm getirmeye çalışan ve bu alanların özelliklerini ülke ortalamasına yükseltmeyi amaçlayan politikalar çerçevesinde şekillenmektedir. Belirlenen hedeflere ulaşabilmek adına bölgenin sahip olduğu kaynakların belirlenmesi, kapasitelerinin analiz edilmesi ve bölgeye yönelik uygulanacak kısa, orta ve uzun vadeli politikaların düzenlenip uygulamaya geçirilmesi gerekmektedir (Akbulut ve Göküş, 2017: 81)

\section{AVRUPA'DA BÖLGESELLEŞME VE BÖLGESEL KALKINMA AJANSLARI}

Avrupa Birliği, Birlik içerisinde sosyal ve ekonomik uyumlaştırmanın oluşturulması, ülkeler arasında var olan farklılıkların giderilmesi ve üye ülkelerdeki bölgesel farklılıkların azaltılması adına ortak bir bölgesel politika geliştirmiştir. Bu politikanın uygulaması da bölgesel kalkınma ajansları ile hayata geçirilmektedir. Bölgesel kalkınma ajansları 1950'lerden itibaren batı Avrupa ülkelerinde faaliyete başlamıştır. 1980 ve 1990'lı yıllarda ise Orta ve Doğu Avrupa ülkelerinde yer alan bölgelerin ekonomik gelişimleri ve kalkınmalarını sağlamak için uygulamaya geçirilmiştir (Kayasü ve Yaşar, 2002: 72). Bölgesel kalkınma ajansları, bölgesel stratejileri gerçekleştirmek, yerel ve bölgesel girişimciliği desteklemek, alt yapı hizmetlerini desteklemek, özel sektörün iyileşmesi adına yerel-bölgesel çözümler ve bölgedeki talepleri karşılayabilmek için finansal çözümler aramak şeklinde sıralanabilecek varlık nedenlerine sahiptir. Bu doğrultuda, 'merkezi iktidardan bağımsız idari bir konumda, sınırları belli bir bölgenin sosyo-ekonomik yapısını iyileştirme amacıyla oluşturulmuş ajanslar' şeklinde tanımlanabilmektedir (Berber ve Çelepçi: 2005: 146). 


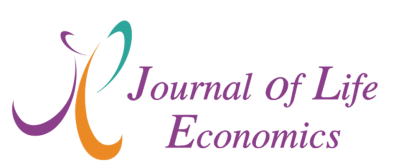

Bölgesel planlamaların tarihsel olarak II. Dünya Savaşı'ndan sonra yaşanan gelişmelerle paralellik gösterdiği anlaşılmaktadır. Ancak, bölgesel kalkınmanın ilk örneği, 1933 yılında ABD'deki Tennessee Vadisinde kurulan ve havza temelli bir bölge planlaması şeklinde faaliyet gösteren "Tennessee Valley Authority" (Tennessee Vadisi İdaresi) olarak karşımıza çıkmaktadır. Benzer bir örnek olarak Güney İtalya'da 1954 yılında Güney Kalkınma Yönetimi adı altında ortaya çıkmıştır (Avaner, 2005: 244).

18. yüzyıldan sonra sanayi devriminin etkisiyle bazı ülkeler hızlı bir büyüme sürecine girmiştir. Bu durum, tüm dünyada bölgeler arasında gelişmişlik düzeylerinin farklılaşmasına sebep olmuştur. Buna benzer bir durum, 1929 ekonomik buhranı döneminde de yaşanmıştır. İkinci Dünya Savaşı'ndan sonra savaşın etkileri ve teknolojide yaşanan gelişimle birlikte Batı ülkelerinde bölgesel farklılıklar daha da artış göstermiştir. Örneğin, Fransa' da Paris bölgesinin gelişiminin yüksek seviyede olması, İtalya' da kuzey ve güney bölgeleri arasındaki farklılıklarının keskinleşmesi, İngiltere, İskoçya ve Galler'de var olan eski sanayilerin işlevselliğini kaybetmesiyle birlikte, bu bölgelerde yeniden yapılanma sorunu oluşmuştur. $\mathrm{Bu}$ durum bölgesel kalkınma sağlanmasına yönelik yeni politikaların oluşturulmasına yol açmıştır. Birleşik Krallık gibi bazı ülkelerde yönetişim anlayışı doğrultusunda bir yapılanma süreci izlenmiş, dolayısıyla yarı özerk ve özel sektörle birlikte kuruldukları da gözlemlenmiştir (Hasanoğlu ve Aliyev, 2007: 88). Bu farklılıkları azaltmak adına Bölgesel Kalkınma Ajansları, bölgesel gelişmenin ve kalkınmanın önemli bir aracı olarak ön plana çıkmaya başlamıştır.

1950'li y1llarda Kuzey Amerika ülkelerinde, Avrupa'da ise Avusturya, Fransa, İrlanda ve Belçika'da kurulmaya başlayan bölgesel kalkınma ajansları, 1960'lı ve 1970'li yıllarda ise Almanya, İngiltere, İtalya ve Hollanda' da faaliyet göstermeye başlamıştır. 1980'li yıllarda Yunanistan, İspanya, Danimarka ve Finlandiya'da, 1990'lı y1llarda ise Bulgaristan, Slovakya, Çek Cumhuriyeti, Estonya, Macaristan, Litvanya, Letonya, Polonya ve Portekiz'de bölgesel kalkınma ajansları kurulmuştur (Çanga, 2010). Bölgesel kalkınma ajanslarının sayısında yaşanan bu artış, aralarında iş birliğinin geliştirilmesi, yeni oluşturulan ajanslara mali ve teknik destek verilmesi, faaliyetler konusunda bilgilendirme yapılması, danışmanlık hizmeti verilmesi ve bölgeler arasındaki dengesizlikleri azaltmak için yapılan planların düzenlenmesi adına 1991 yılında Brüksel'de, “Avrupa Kalkınma Ajansları Birliğii” (EURADA) kurulmuştur (Tamer, 2008: 73).

Küreselleşme süreci ile birlikte ulusal kalkınma yerini 1990'larda bölgesel kalkınma anlayışına bırakmıştır. Ayrıca, 'yönetim' kavramı yerine 'yönetişim' kavramı kullanılmaya başlanmıştır. Küreselleşme süreci, bölgesel kalkınma politikalarının da değişmesine yol açmıştır. 1960'lı ve 1970'li yıllarda 'merkezileşme' adı altında yukarıdan aşağıya doğru uygulanan bölgesel politikalar; 1970'lerden itibaren 'içsel kalkınma', 1980'li yıllardan itibaren ise, bölgeselleşme yaklaşımı çerçevesinde aşağıdan yukarıya doğru şekillenmiştir. Bölgesel politikalarda, merkezi ve yerel aktörler arasındaki iletişimi ve iş birliğini sağlayacak bir kurumsal yapının varlığı gerekmektedir. Bölgesel düzeyde oluşturulan bu kurumsal yapı ise bölgesel kalkınma ajansları olarak karşımıza çıkmaktadır (Çelik, 2017: 58).

Bölgesel kalkınma ajansları ülkeden ülkeye farklı nitelikler gösterebilmektedir. Ancak temelde aynı ortak hedeflere sahiptirler. Bölgesel kalkınma ajanslarının bazı ortak özellikleri arasında; kurumsal kimliğe sahip olmaları, siyasi otoriteye karşı özerk veya yarı-özerk şekillerde örgütlenebilmeleri, yerel ve bölgesel ihtiyaçları karşılayabilecek faaliyetlerde bulunmaları ve değişime açık olmaları sayılabilmektedir (Akbulut ve Göküş, 2017: 82).

Avrupa' da bölgesel kalkınma ajansları, yerel ve bölgesel gelmişlik düzeyi sorunlarını çözebilmek adına iç dinamikleri harekete geçirebilen, bölgede ekonomik kalkınma için 


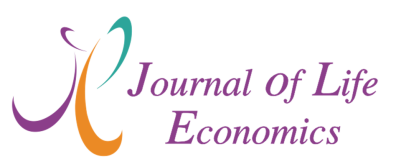

girişimcileri destekleyen ve ülke çapında kalkınmanın gerçekleştirilmesi amacını taşıyan kuruluşlar olarak nitelendirilmişlerdir (Tahtalığlu ve Özgür, 2016: 163). Avrupa Bölgesel Kalkınma Ajansları Birliği'ne (EURADA) üye olan yaklaşık 150 bölgesel kalkınma ajansı bulunmaktadır. Ancak bu birliğin üyeleri arasında bile standart bir model söz konusu değildir. $\mathrm{Bu}$ farklılıkların karşılaştırılması adına, Avrupa Birliği üyeleri arasından seçilen ülkeler bağlamında bir karşılaştırma yapılması planlanmaktadır. Bunun için öncelikle Birliğin kurucu üyelerinden Fransa'nın bölgesel yapısı ve bölgesel kalkınma ajansları incelenecektir.

\section{FRANSA'DA BÖLGESELLEŞME HAREKETLERİ VE BÖLGESEL KALKINMA AJANSLARI}

Fransa'da bölgeselleşme hareketlerinin 200 yıldan daha fazla geçmişe sahip olduğu söylenebilmektedir. Fransa 1789 Fransız Devrimi'ne kadar imparatorluğun en güçlü ve iyi organize olmuş bölgesi olarak görülmüştür. 987'de kral seçilen Hugues Capet zamanında kurumsallaşma süreci gerçekten başlamış ve bu dönemde Ile-de-France prensliği Fransa'nın en güçlü bölgesi haline gelmiştir. 8 yüzyıl boyunca bu prensliğin gücünü devam ettirmesinin ardından 1789 Fransız Devrimi ile bir anayasa oluşturulmuş ve yeni bir reform süreci başlatılmıştır. Önceki yönetim şeklinin üzerine yeni kurumlar eklenmesine rağmen bölgeler, hala ayrıcalıklı seçkinler tarafından temsil edilmekte; küçük bölgelerin her birinin bir başkenti bulunmakta, büyüklükleri ve yerleşim yerleri ise atla ne kadar sürede ulaşıldığına bakılarak ölçülmekteydi (Okçu ve diğg, 2009: 41).

20. yüzyılda Fransa'da bölgeselleşme adına yapılan faaliyetler incelendiğinde ilk olarak, Charles De Gaulle'un 1944'te çıkardığı bir yönetmelikle güvenlik konularında özel bölgesel temsilcilikler ve bölgesel komiserlikler oluşturduğu görülmektedir. 1944-1963 yılları arasında ekonomik gelişmede bölgelerin önemli olduğu düşünülmeye başlanmıştır. Ayrıca, İkinci Dünya Savaşı'ndan sonra Fransa'nın, Marshall yardımlarından yararlanması dolayısıyla, bu fonların yönetilmesi ve eşit dağıtılması amacıyla bölgesel politikaların ön plana çıkmaya başladığı görülmektedir (Azam-Pradeilles, 2008) II. Dünya Savaşı'ndan sonra 1950 yılında, Fransa Alsace Bölgesi Kalkınma Ajansı, bu bölgenin ekonomisini yeniden canlandırmak hedefiyle kurulmuştur, ayrıca hem Fransa'nın hem de Avrupa'nın kurulan ilk kalkınma ajansı olmuştur (Apalı ve diğ., 2014: 79).

1954 yılında özel sektör temelli olarak oluşturulan "Bölgesel Kalkınma Komiteleri” 30 Haziran 1955 tarihinde bir kararname ile resmiyet kazanmıştır. Buna göre Fransa, 21 ekonomik bölgeye ayrılmıştır. Ancak bu bölgeler içerisinde Paris bölgesinin çok fazla geliştiği ve diğer bölgelere eşitsiz dağılım olduğu düşüncesi tartışmalara yol açmaya başlamıştır. Fransa'da bu dönemde endüstriyel işletmelerin özellikle kömür yataklarının bulunduğu alanlarda yani Fransa'nın kuzey bölgelerinde kurulmaya başlanması söz konusu olmuştur. Maden kaynakları ve toprak şartları açısından elverişli konumda bulunan kuzey Fransa, güney Fransa'ya göre çok daha hızlı bir gelişim sergilemiştir. Bu durum da, Fransa'nın bölgeler arasındaki eşitsiz dağılıma sebep olan etmenlerden birini teşkil etmektedir. 1963 yılında Fransa'da, 'Ülke Düzenleme ve Bölgesel Aksiyon Delegasyonu' (Delegation Al'amenagementdu Territoire et Al'action Regionane-DATAR) kurulmuştur. DATAR, Fransa'daki bölgesel kalkınma yapılanmalarının kurumsal alt yapısını teşkil etmektedir. Kurumun kurulduğu ilk yıldaki hedefi ve görevi ise Paris bölgesi ile Fransa'nın diğer bölgeleri arasında dengenin sağlanması şeklinde belirlenmiştir (Apalı ve diğ., 2014: 79).

Seçilmiş bir hükümet ile idari bölgeler oluşturmak isteyen De Gaulle, 1969'daki referandumda onay almayı başaramamıştır. Fransızların hayır oyu bölgeler sisteminden çok De Gaulle'un kendisine olmasına rağmen bu durum Fransa' da bölgeselleşme hareketlerinin yavaşlamasına yol açmıştır. 1972' de yayınlanan bir yasa ile bölgeselleşme sürecinde yeni bir 


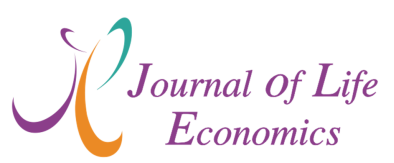

dönem başlamıştır. Bölgelerin, "Bölgeler Konseyi” adı verilen bir kurum ile örgütlenmesine karar verilmiş böylece bölgeler yasal bir varlık haline gelerek, kendilerine ait bir bütçeleri olmuştur. Ancak hala üyeleri demokratik olarak seçilmemektedir ve özerk bir yapıya sahip değildir. 1982-1983'de oluşturulan yasalarla ilk adem-i merkeziyetçi yapılanmalar görülmeye başlanmıştır. Bölgeler, yasal ve özerk topraklar haline gelmiş, vergileri artırma ve kendi bütçelerini yönetme güçleri oluşmuştur (Okçu ve diğ, 2009: 43). Böylece adem-i merkeziyetçi, üniter bir devlet olan Fransa'da 1961 yılında, bölgesel faaliyetlerin düzgün yürütülebilmesi adına idari bir bölünme yaşandığı, daha sonra 1972'de devlet tarafından oluşturulan kamu kuruluşu niteliğindeki bölgelerin ortaya çıktığı ve 1982 yılında ise adem-i merkeziyet hakkındaki kanunlar vasıtasıyla seçilmiş bir meclis tarafından yürütülen yerel bir topluluk olan bölgelerin kendine özgü yetkilere sahip olduğu görülmektedir. Fransa'da 2 ya da 8 vilayetin/ilin bir araya gelmesi sonucunda oluşan toprak bütünü şeklinde ifade edilen bölgelerin başlıca yetkilerini: "Binalar, liselerin iyi işleyişi, taşımacılık ve bölge çıkarları için bağlantılar, saha 1slahı, ekonomik gelişme, devletle görüşme ve devlet-bölge planının yürürlüğe konması ve mesleki eğitim" şeklinde sıralamak mümkün olmaktadır. Sonuç olarak, ekonomik gelişme ve ülke topraklarının ıslahı gibi faaliyetlerin, bölgeler düzeyinde yürütüldüğü anlaşılmaktadır (Fransa AB Bakanlığı, 2017).

Fransa'da 4 tanesi deniz aşırı iller olmak üzere, toplam 100 il bulunmaktadır. Fransa yerel idaresinin yapılanmalarından bir tanesi olan bölgenin, 16 Mart 1986 tarihinde ülke toprağ1 kolektivitesi olarak değerlendirildiği görülmektedir. Bu durum, 28 Mart 2003 tarihinde yapılan anayasal düzenlemeyle yasallık kazanmıştır. Bu dönemden itibaren Fransa'da 4'ü deniz aşırı iller olmak üzere 26 adet bölge bulunduğu bilinmektedir (Okçu ve diğ, 2009: 45).

2003 yılında Fransız anayasasında Fransa'nın adem-i merkezi idari bir yapıya sahip olduğu ifade edilmektedir. Anayasanın 74. maddesi yerel ve bölgesel özerkliği güçlendirmekte ve daha fazla mali güçleri olduğunu göstermektedir Anayasanın 72. maddesi ile Fransa'nın bölgeleri hakkında genel bir bilgi vermektedir. 3. paragrafta seçilmiş üyeleri bulunan konseye ve karar alma mekanizmasına sahip olan bölgelerin kendi kendilerini idare edebilecekleri söylenmiştir. 5. paragrafta hiçbir yerel birliğin diğeri üzerinde gücü olmadığı, fakat ortak bir projede diğerlerinin de onayı ile bir takım liderinin belirlenebileceğine değinilmiştir Fransa'nın 5. Cumhuriyet Anayasası olarak da ifade edilen bu düzenlemeyle, Fransa'da bulunan 26 bölgenin her birinin yönetiminin bir vali tarafından yürütüldüğü görülmektedir (Apan, 2004: 4).

\section{INGIILTERE'DE BÖLGESELLEŞME HAREKETLERİ VE BÖLGESEL KALKINMA AJANSLARI}

İngiltere'de bölgesel kalkınma ajansları, 1998 yılında çıkarılan "Bölgesel Kalkınma Ajansları Kanunu"na dayanarak oluşturulmuştur. 1999 yılında sekiz, 2000 yılında ise Londra'da Londra Kalkınma Ajansı (London Development Agency-LDA)'nın kurulması ile birlikte İngiltere'de toplamda dokuz bölgesel kalkınma ajansı kurulmuş ve faaliyet göstermeye başlamıştır (Demirel, 2014: 88). İngiltere' deki faaliyet gösteren bölgesel kalkınma ajansları, bakanlık dışı kamu kuruluşu ve özerk örgüt yapısına sahiptirler. Bu ajansların finans kaynakları, merkezi yönetimlerden ve bakanlıklardan aktarılan paylardan oluşan kamu gelirleri ve Avrupa Birliği yapısal fonlarından oluşmaktadır (Köse ve Konur, 2011: 103).

BKA'ların kuruluş amacı, İşçi Partisi'nin hükümeti döneminde geliştirilen ekonomik kalkınma politikalarına daha üst seviyede bir bölgesel işlevin dâhil edilmesi şeklinde belirlenmiştir. İngiltere' de bölgesel kalkınma ajansları, 2001'e kadar Çevre, Ulaşım ve 


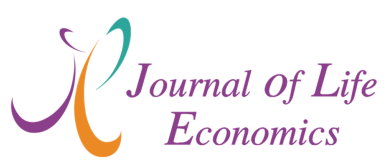

Bölgeler Bakanlığı'na bağlıyken, bu yıldan sonra sorumluluklar Ticaret ve Sanayi Bakanlığı'na bırakılmıştır. Londra Kalkınma Ajansı dışındaki diğer ajanslar ise yarı-kamu kurumu statüsünde oluşturulmuştur (Demiroğlu ve Demiroğlu, 2014: 188)

İşçi Partisi yönetiminde, yerinden yönetim uygulamaları desteklenmiş ve politik hedeflere sahip olan bölgeselleşme düzenlemeleri oluşturulmuştur. Ayrıca İşçi Partisi ekonomik amaçlı bölgeselleşmeyi desteklemektedir. Bu amaçla da, ekonomik gelişmişlik ve kalkınma düzeylerini yükseltme, bölgeler arasında var olan eşitsizlikleri en az indirgeme ve sürdürülebilir kalkınma gibi hedefler belirlenmiş ve bu hedefleri içeren Bölge Kalkınma Ajansları Yasası'nı çıkartmıştır. Bu yasa ile kurulan Bölge Kalkınma Ajansı sayısı 8 olmakla birlikte, bu bölgelerin hepsinde ayrı Bölge Kurulları kurulduğu da görülmektedir. Bölge kurulları, ülkedeki bölgelerin ekonomik stratejilerinin hazırlanması sürecinde kalkınma ajanslarına danışmanlık yapmaktadır. Bu kurulların üye sayısı, bölgelerin fiziki ve politik yapılarına göre farklı belirlenmiştir (Demiroğlu ve Demiroğlu, 2014: 188). Temmuz 2000'de ise İngiltere'de daha önce kurulmuş olan 8 bölgesel kalkınma ajansına dokuzuncusu eklenmiş ve Londra Kalkınma Ajansı kurulmuştur. Sonuç olarak, tüm bölge kalkınma ajanslarının sınırları çoğunlukla bölge idareleri ile benzer olacak şekilde ele alınmıştır (Demirel, 2014: 88)

2012 yılında İngiltere'deki bölgelerde ekonomik kalkınmanın sağlanması, yerel ortakların kurduğu iş birliklerinin arttırılması ve bölgesel kalkınma ve gelişim düzeylerindeki farklılıkların en aza indirgenmesi amaçlarını düzgün bir şekilde yerine getiremeyen kalkınma ajanslarının kapatıldığı görülmektedir. Yarı kamusal nitelik taşıyan ve bütçesinin çoğunun devlet tarafından karşılandığı İngiltere' deki bu eski ve işlevsiz kalkınma ajanslarının yerine, yerel ekonomiyi kalkındırmak ve geliştirmek amaçlı Yerel Girişim Ortaklıkları kurulmuştur (Tahtalığlu ve Özgür, 2016: 164).

\section{POLONYA'DA BÖLGESELLEŞME HAREKETLERİ VE BÖLGESEL KALKINMA AJANSLARI}

Polonya'nın 1990'lı yıllardan beri uyguladığı istikrarlı ekonomik liberalizasyon politikaları sonucunda, geçiş ekonomileri bağlamında değerlendirildiğinde başarılı bir ekonomik yapıya sahip olduğu söylenebilmektedir. Polonya, 2004 yılında AB üyesi olmakla birlikte, aslında 1990'lı yıllar boyunca büyük bir değişim ve dönüşüm yaşamıştır. Bu dönüşüm sürecinde, bu dönemde kurulan bölgesel kalkınma ajanslarının rolü büyüktür (Köse ve Konur, 2011: 120).

Orta ve Doğu Avrupa ülkelerinin büyük bir kısmında bölgesel kalkınma ajansının tanımı ve içeriği Avrupa'dan transfer edilmiştir. $\mathrm{Bu}$ ülkelerin $\mathrm{AB}$ üyesi olmasıyla ilk kalkınma ajansları kurulmuş ve AB tarafından da desteklenmiştir. 1990'lı yıllarla AB üyeliği gündeme gelen Orta ve Doğu Avrupa ülkeleri kendi kurumsal yapılanmaları içerisinde yer almayan yeni yapılanmalarla tanışmışlardır. $\mathrm{Bu}$ ülkelerde özelleştirmenin ve özel sektörün ulaştığı aşama ve merkezi devletin küçülmeye gitmesi, kalkınma ajanslarını etkileyerek daha işlevsel hale getirmiştir (Özen, 2005: 7). İşlevsellikten yararlanan ülkelerden biri olan Polonya'yı diğer Avrupa ülkelerinden ayıran en temel özellik, AB'nin PHARE programı kapsamında Orta ve Doğu Avrupa ülkelerine yönelik bölgesel yapılar kapsamındaki ilk çalışmayı başlatmasıdır. Diğger Avrupa ülkelerinden farklı olarak, bölgesel yapıların ekonomik boyutu dışında idari boyut da kazanmış olması ve ayrıca idari reformlar açısından öncü bir ülke olması da önem teşkil etmektedir (Tuncer, 2012: 68). 1998 y1lında Polonya Parlamentosu, kamu yönetimi ve kamu yönetimi finans açısından daha da merkezi olmayan bir dizi kanun yürürlüğe koymuştur (Kilianski, 2011: 10). Yine 1998'de Polonya'nın AB'ye yakın bir politika izlemesi, merkezi teşkilatın bölgesel düzeyde yeni bir örgütlenme oluşturmasını gerektirmiştir. Bu açıdan 49 il birleştirilmiş ve bölgesel düzeyde temel alınan 


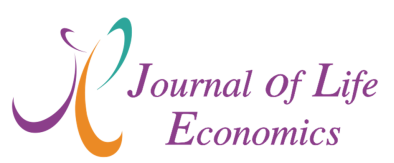

16 yeni il oluşturulmuştur. Böylelikle Polonya 16 bölgeden oluşur hale gelmiştir. Ayrıca, AB seviyesinde etkin veri toplanması hedefiyle NUTS (Nomenclature of Territorial Units For Statistics/İstatistiki Bölge Birimi Sınıflandırma Sistemi) sistemi kabul edilmiş ve böylece Polonya 5 NUTS birimine bölünmüştür (Özen, 2005: 8).

Polonya'daki BKA'ların yapılarına bakıldığında çalışma alanları ve özelliklerinin bölgelere göre farklılıklar gösterdiği anlaşılmaktadır. Bu farklılıkların nedenlerini, bölgelerin mevcut özellikleri, sermaye sahiplerinin istekleri ve finansal kaynakların farklılığı şeklinde sıralamak mümkün olmaktadır (Köse ve Konur, 2011: 121). Bununla birlikte Polonya' da, Polonya Bölgesel Kalkınma Ajansı (PARD), Bölgesel Kalkınma Ajansları Ulusal Birliği (NARDA) ve Sanayi Kalkınma Ajansı'nın (IDA) merkezi hükümet düzeyinde örgütlendiği ve BKA'ların işlevlerinden sorumlu olduğu anlaşılmaktadır. PARD, AB fonlarının kalkınma ajansları arasında dağıtımını denetleyen ve koordinasyonu sağlayan kamu otoritesi olarak faaliyet gösterirken; IDA yerel düzeyde çalışan birçok ajansın sermaye ortağı olarak nitelendirilmektedir. NARDA ise kalkınma ajansları için eğitim, ağ oluşturma, bilgi değişimi gibi çalışmaları yürüten bir sivil toplum kuruluşu olarak kendisini göstermektedir (Özen, 2005: 10).

Polonya'da merkezi yönetim kalkınma ajanslarının kontrolünü kendisi yapmaktadır. Ancak bunu BKA'lara kamu kurumu kimliği vermeden, değişik kurumlar vasıtasıyla gösterme yolunu seçmiştir. Böylece Polonya' da kalkınma ajansları, idari yapılanmalar içinde kendine düzgün bir yer sağlamakta başarılı olamamıştır. BKA'ların idari yapılanmalar içinde uyumlu faaliyet gösterebilmesi için başlangıçta ajansların kamu kurumu olarak oluşturulması önem teşkil etmektedir. Ancak bu durumda, resmi statüleri itibariyle daha etkin bir faaliyet bölgesine kavuşabilmektedirler. Ancak Polonya'da merkezi yönetim ile özel sektör arasında aracılık yapması ve iş birliğini sağlaması umut edilen BKA'lar, Avrupa'daki benzerlerinden farklılaşarak kâr amacı güden şirket statüsünde değerlendirilmektedir (Tuncer, 2012: 69).

Polonya'da BKA'lar bölgelerin sosyal ve ekonomik dönüşümüne ve kalkınmasına önemli katkılar yapmaktadır. Devletçi yatırım politikalarının uygulandığı Polonya' da bölgesel kalkınma ajansları, kamu ve özel sektörü bir araya getiren çalışmalarda bulunmuş ve başarılı adımlar atmışlardır. Özellikle Polonya' da bölgesel gelişmişlik farklarının varlığı nedeniyle gelişmiş ve az gelişmiş bölgelerde uygulanan politikalar arasında farklılıklar bulunmaktadır. Sanayi bölgelerinde kurulmuş kalkınma ajanslarının, insani sermaye ya da mali kaynaklara daha kolay ulaşabilmesi, gerçekleştirebildiği proje sayısının fazla gözükmesine sebep olmaktadır. Bölgenin ihtiyaçlarıyla bağdaşmayan, merkezi kurumlar tarafından hedeflenen politikalar, Polonya' daki kalkınma ajansları için bir engel teşkil etmektedir. Polonya'nın AB fonlarından büyük oranda faydalanmasına rağmen, mali yetersizliğin halen önemli bir sorun olması ise diğer bir engel olarak karşımıza çıkmaktadır (Köse ve Konur, 2011: 132).

Sonuç olarak, Polonya'da bölgesel kalkınma ajanslarının gelişerek yerel ve bölgesel ekonomilerin dönüşümünde çok önemli oldukları görülmektedir. Bu açıdan Polonya'daki bölgesel kalkınma ajanslarının getirdiği yeniliklerden en önemlisi, özel sektör ile kamu sektörü arasında sert bir ayırımın bulunduğu bu ülkede, kamu sermayesi ile özel sermayeyi bir araya getirebilen yeni bir yapının varlığını sürdürebilme başarısı şeklinde ifade edilebilmektedir. Karşılaştıkları tüm hukuksal, kurumsal ve ekonomik güçlüklere rağmen bölgesel kalkınma ajansları bu yeni yapıyı kabul ettirmeyi başarmıştır (Özen, 2015: 17). 


\section{7. ÇEK CUMHURIYETI'NDE BÖLGESELLEŞME HAREKETLERİ VE BÖLGESEL KALKINMA AJANSLARI}

Avrupa Komisyonu siyasi bir bölgeselleşmeden yana gibi gözükmesine rağmen, özellikle yapısal fonların yürütülmesi bağlamında, Doğu ve Orta Avrupa ülkelerinin Avrupa Birliği'ne adaylıkları süresince merkezileşmeyi teşvik ettiği görülmektedir. Bunun sebebi ise, bu ülkelerin kurumsal kapasitelerinde bir eksiklik olması şeklinde değerlendirilebilmektedir (Ertugal, 2007: 230). Sosyalist bir geleneğe sahip olan Çek Cumhuriyeti'nde, bölgeselleşme politikaları 1990'lı yıllarla beraber gündeme taşınmıştır. Bu politikalar devletin serbest piyasa ekonomisi açısından etkinlik aracı olarak değerlendirilmiş ve bu kapsamda 1996 yılında kurulan "Bölgesel Kalkınma Bakanlığı" ülkede uygulamaya yönelik en önemli adımlardan birini oluşturmuştur. $\mathrm{Bu}$ bakanlık bölgeler arası eşitsizliklere çözüm bulmak ve $\mathrm{AB}$ fonlarından yüksek düzeyde istifade edebilmek amacina hizmet etmektedir (Yılmaz ve Doğan, 2013: 22).

Bununla birlikte ülkede, piyasa ekonomisinin etkin ve verimli bir şekilde ilerlemesini sağlamak için "Bölgesel İktisadi Politikanın İlkeleri”" yasası kabul edilmiştir. Bölgesel kalkınmanın sağlanması için bu konuyla ilgili özel bir bakanlık oluşturulması yaklaşımı sadece Orta ve Doğu Avrupa ülkelerinde değil Batı Avrupa'da da pek benzeri olmayan bir durum olarak karşımıza çıkmaktadır. Çoğu ülkede bölgesel politikanın gerekleri faaliyette olan herhangi bir bakanlı̆̆ın içerisinde oluşturulan yeni bir birime verilmiştir. Ayrıca Bölgesel politikanın gelişiminde Çek Cumhuriyeti'nde görülen en önemli olay, "Çek Cumhuriyeti'nin Avrupa Birliği' ne Üyelik Başvurusu Hakkında Avrupa Komisyonu'nun Görüşü” belgesinin 1997 yılında yayımlanması olmuştur. Komisyon bu belgede "Çek Cumhuriyeti'nde bölgesel bir politika bulunmamaktadır" görüşünü sunmuş ve bu eleş̧iriler durumu büyük ölçüde etkilemiştir. Böylece Aralık 1997'de seçilmiş ve özerk 14 bölgesel idari birimin kurulmasına imkân veren yeni bir yasa kabul edilmiştir (Haşar, 2007: 5).

Sonuç olarak ifade etmek gerekirse, Çek Cumhuriyeti'nde Bölgesel Kalkınma Ajansları devletten bağımsız hareket etmektedir ve ilk kurulan Ostrava ve Most ajansları dışında hiçbiri devlet tarafından kurulmamıştır (Haşar, 2007: 18).

\section{SONUÇ VE DEĞERLENDİRME}

Bölgeselleşme hareketleri ve bölgesel yönetim modelleri her ülkede farklllık göstermekte, hatta aynı ülke içerisinde farklı bölgelerde bile değişik şekillerde uygulanabilmektedir. İngiltere ve Fransa Avrupa Birliği içerisinde, kendi ülkelerinde bölgesel eşitsizliğin ve dengesizliğin en çok göründüğü ülkeler arasında yer almaktadırlar. İngiltere'de bölgesel eşitsizlikler, Fransa'da olduğu gibi çok daha eskilere dayanmaktadır. Ancak Fransa'da bölgesel politikaların somut uygulamaları II. Dünya Savaşı'ndan sonra başlamışken, İngiltere'de ilk bölgesel politikalar 1960'lı yıllardan itibaren uygulamaya geçirilmiştir. Polonya ve Çek Cumhuriyeti ise bölgeselleşme hareketlerini 1990'lardan sonra somutlaştırabilmiştir.

Günümüzde Avrupa Birliği üye ülkelerindeki bölgelerin ekonomik gelişme adı altında gittikçe özerkleşmesi ve yabancı yatırımcıların çekilmesi adına kalkınma yarışı içerisine girmesi, bölgeleri bölgesel kalkınma ajansları oluşturmaya teşvik etmektedir. Fransa'da kurulan ilk bölgesel kalkınma ajanslarından olan Alsace Bölgesel Kalkınma Ajansı ve İngiliz Bölge Kalkınma Ajansı da bu doğrultuda faaliyete başlayan ajanslar arasındadır.

Fransa'da tüm bölgesel ajansların bağlı bulunduğu DATAR gibi bir kurum bulunmaktadır. Polonya'da ise Bölgesel Kalkınma Ajansları Ulusal Birliği olan NARDA bu 


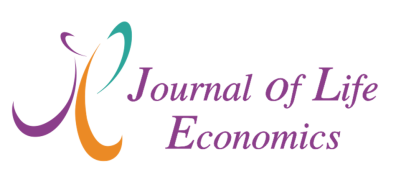

görevi üstlenmektedir. Ancak İngiltere' de ve Çek Cumhuriyeti'nde DATAR ve NARDA gibi ajanslar ve bakanlıklar arasında arabuluculuk yapan bir üst yapı mevcut değildir.

İngiltere ve Fransa' da faaliyet gösteren kamu kuruluşu niteliğindeki bölgesel kalkınma ajansları, 1990'larda merkezi devletin kamu kaynaklarıyla desteklenmeye başlamış, AB Yapısal Fonlarının bölgede verimli şekilde kullanılmasını sağlamakla görevlendirilmiştir. İngiltere'nin 9 kalkınma ajansından 8'i bakanlık dışı oluşturulan kamu kurumu olma niteliğine sahipken, Londra Kalkınma Ajansı belediyeler tarafından kurulan bir kalkınma ajans olma özelliği taşımaktadır. Fransa' da faaliyet gösteren ajanslar ise belediyeler ve özel sektör tarafından oluşturulan kalkınma ajansları şeklinde faaliyet göstermektedir. Çek Cumhuriyeti'ndeki kalkınma ajanslarından 2'si dışındaki kalkınma ajansları devlet tarafından oluşturulmamış ve bağımsız nitelik taşımaktadır. Polonya'da ise başlangıçta kamu kurumu olarak kurulan kalkınma ajansları genelde merkezi hükümet düzeyinde bir örgütlenme sergilemektedir.

Görüldügüü üzere bölgesel kalkınma ajanslarının bazıları, Fransa'da olduğu gibi yasal düzenlemeler ve kanunlarla oluşturulmuşken, İngiltere' de Bakanlık dışı kamu kurumu yani özerk örgüt şeklinde örgütlenmekte, Polonya ve Çek Cumhuriyeti’nde ise kamu-özel sektör şirketleri şeklinde faaliyet göstermektedir. Ayrıca bölgesel kalkınma ajanslarının yasal statüleri son zamanlarda merkezden daha özerk olmaları adına daha otonom hale getirilmiş ya da özelleştirilmiştir. Kuruluş şekilleri ve işleyişleri ülkeden ülkeye ve hatta bölgeden bölgeye farklılık gösterse de, bölgeselleşme sürecinde farklı politikalar izlense de, bölgesel kalkınma ajanslarının en önemli amacı olan, ülkenin ekonomik kalkınmasına katkı sağlamak, tüm bölgesel kalkınma ajanslarını ortak paydada buluşturan önemli bir etken olarak karşımıza çıkmaktadır. 


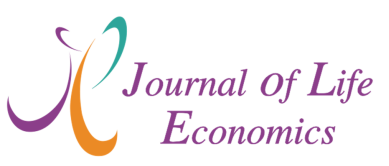

\section{KAYNAKÇA}

"Fransız Topraklarının Siyasi ve İdari Organizasyonu”, Fransa AB Bakanlı̆̆l, [online], https://cy.ambafrance.org/Fransiz-topraklarinin-siyasi-ve, [Erişim Tarihi: 02 Ekim 2017].

AKBULUT, M.U.F. ve GÖKÜŞ, M., 2017, "Küreselleşme ve Yerelleşme Sürecinde Bölgesel Kalkınma Ajansları", Selçuk Üniversitesi Sosyal Bilimler Meslek Yüksekokulu Dergisi, Cilt.20, No.1, 79-88.

AKİŞ, E., 2011, "Küreselleşme Sürecinde Bölgesel Kalkınma Yaklaşımındaki Gelişmeler ve Bölgesel Kalkınma Ajansları”, Sosyoloji Konferansları Dergisi, No.44, 245.

APALI, A., YILDIZ, N., BOZTEPE, E. ve BAYRAK, S., 2014, "Bölgesel Kalkınma Ajansları: Fransa ve İngiltere Örnekleri”, Karadeniz, Cilt.6, No.23, 66-88.

APAN, A., 2004, "Bölge Kavramı ve Bölgesel Kalkınma Ajansları", Çağdaş Yerel Yönetimler Dergisi, Cilt.13, No.4, 39-58.

AVANER, T., 2005, “BKA Siyasal Rejim Sorunu Yaratır mı?”, Bölgesel Kalkınma Ajansları Nedir, Ne Değildir?, Der. Menaf Turan, Ankara.

AZAM-PRADEILLES, A. 2008, "Regionalism Seen From the National Perspective: The French Process of Regionalisation", Models of Regional Development, Unidem Campus Trieste Seminar, Trieste, Italy, 21-24 April 2008.

BERBER, M. ve ÇELEPÇİ, E., 2005, “Türk Bölgesel Kalkınma Politikalarında Yeni Arayışlar: Kalkınma Ajansları ve Türkiye'de Uygulanabilirliği”, Karadeniz Bölgesel Kalkınma Sempozyumu, Bildiriler Kitabı, 13-14 Ekim 2005, Trabzon, 146-155.

BRASCHE, U., 2001, Avrupa Birliği'nin Bölgesel Politikası ve Türkiye'nin Uyumu, İKV Yayınları, İstanbul.

ÇANGA, E., 2010, “Kalkınma Ajansları”, Кати Yönetimi ve Reform, No.9.

ÇELIK, F., 2017, “İzmir Kalkınma Ajansı (İZKA) Kalkınma Kurulu’nun Etkinliğini Artırma Girişimleri”, Süleyman Demirel Üniversitesi Sosyal Bilimler Enstitüsü Dergisi, Cilt.27, No.2, $55-80$.

DEMIREL, D., 2015, “İngiltere'de 1990 Sonrası Bölgeselleşme Politikaları” Kahramanmaraş Sütçü İmam Üniversitesi İktisadi ve İdari Bilimler Fakültesi Dergisi, Cilt.4, No.2, 85-94.

DEMIROĞLU M. ve DEMİROĞLU E. T., 2014, “Türkiye ve İngiltere Kalkınma Ajansları: İngiltere Deneyiminden Alınabilecek Dersler”, Elektronik Sosyal Bilimler Dergisi, Cilt.13, No.48, 176-199.

ELMAS, G., 2001, Küreselleşme Sürecinde Bölgesel Dengesizlikler, Nobel Yayın, Ankara.

ERTUGAL, E., 2007, “AB Bölgesel Politikalarının Üye ve Aday Ülkelere Etkileri”, 2. Bölgesel Kalkınma ve Yönetişim Sempozyumu “Çok Düzlemli Yönetişim”,25-26 Ekim 2007, Tepav Yayınları, No: 37, İzmir.

HASANOĞLU, M. ve ALIYYEV, Z., 2007, “Avrupa Birliği ile Bütünleşme Sürecinde Türkiye'de Bölgesel Kalkınma Ajanslart”, [online] http://www.sayistay.gov.tr/yayin/dergi/icerik/der60m5.pdf, [Erişim Tarihi: 01 Ekim 2017].

HAŞAR, Ç., 2007, “Çek Cumhuriyeti’nde Bölgesel Kalkınma”, Türkiye Ekonomi Politikaları Araştırma Vakfı Yönetişim Etütleri, [Erişim Tarihi: 05 Ekim 2017]. 


\section{$\int\left(\begin{array}{c}\text { Journal of Life } \\ \text { Economics }\end{array}\right.$}

KAYASÜ, S. ve YAŞAR, S.S., 2002, "Değişen Bölge Kavramı ve Bölgesel Ekonomik Kalkınma: Bölgesel Kalkınma Ajansları”, 10. Bölge Bilimi/Bölge Planlama Kongresi: Avrupa Birliği ile Uyum ve Bütünleşme, 80-97.

KILIANSKI, T., 2011, "Regional Development Agencies Country Case Study: Poland", [online], http://rsedp2serbia.eu/files/wp-content/uploads/2011/09/RDA-Case-Study-Poland2011-03-03.pdf, [Erişim Tarihi: 08 Ekim 2017].

KÖSE, S. ve KONUR F., 2011, “Avrupa Birliği ve Türkiye'de Bölgesel Kalkınma Ajanslarının Bölgesel Farkların Azaltılmasındaki Rolü ve Etkililiği: Ülke Deneyimlerinin Karşılaştırılması”, Ekonomik ve Sosyal Araştırmalar Dergisi, Cilt.7, No.1, 95-137.

MENGİ, A., 1998, Avrupa Birliği’nde Bölgeler Karşısında Yerel Yönetimler, İmaj Yayıncılık, Ankara.

OKÇU M. ve diğ., 2009, "Türkiye ve Fransa'da Yerelleşme ve Bölgeselleşme: AB Çok Düzlemli Yönetişim Sistemi Çerçevesinde İki Üniter Devlet İçin Karşılaştırmalı Bir Analiz”, Proje No:107K336, 1-144.

ÖZDEMIR, Z. 2014, “Türkiye ve Fransa: İki Üniter Devletin Adem-i Merkeziyetçilik Yaklaşımı”, Akademik http://akademikperspektif.com/2014/02/19/turkiye-ve-fransa-iki-uniter-devletin-ademmerkeziyetcilik-yaklasimi/, [Erişim Tarihi: 01 Ekim 2017].

ÖZEN, P., 2005, "Polonya'da Bölgesel Kalkınma Ajansları", [online], http://www.tepav.org.tr/tr/yayin/s/173, [Erişim Tarihi: 05 Ekim 2017].

TAHTALIOĞLU, H. ve ÖZGÜR, H., 2016, “Türkiye'de Kalkınma Ajansları Politikasının Çözümlenmesi: Süreç Analizi (Aşamalar Yaklaşımı) “, Niğde Üniversitesi İktisadi ve İdari Bilimler Fakültesi Dergisi, Cilt.9, No.3, 161-184.

TAMER, A., 2008, "Kalkınma Ajanslarının Türk Hukuk Sistemindeki Yeri”, DPT Uzmanlık Tezi, No.2757.

TUNCER, A., 2012, "Merkeziyetçilikten Hiyerarşik Yönetişime: Polonya' da Bölge Politikaları", Finans Politik \& Ekonomik Yorumlar, Cilt.49, No.573, 67-78.

YILMAZ, N. ve DOĞAN, K. C., 2013, “Avrupa Birliği (AB) Talepleri Doğrultusunda Çek ve Romanya Cumhuriyetleri'nin Demokratikleşme Reformları”, Karadeniz Araştırmaları, Cilt.39, 15-29. 